\title{
Deteç̧ão de anticorpos anti-Toxoplasma gondii em suínos criados e abatidos no Estado da Bahia, Brasil
}

\author{
Detection anti-Toxoplasma gondii antibodies in swines bred and abated in the Bahia State, Brazil \\ Rodrigo A. Bezerra ${ }^{1}$; Elisson B. Paranhos²; Ana Elisa Del'Arco ${ }^{3}$; George R. Albuquerque ${ }^{4 *}$ \\ ${ }^{1}$ Programa de Pós-Graduação em Ciência Animal, Universidade Estadual de Santa Cruz - UESC / Bolsista CAPES \\ ${ }^{2}$ Graduação em Medicina Veterinária, Universidade Estadual de Santa Cruz - UESC / Bolsista PIBIC/CNPq \\ ${ }^{3}$ Centro de Ciências Agrárias, Ambientais e Biológicas, Universidade Federal do Recôncavo da Bahia - UFRB \\ ${ }^{4}$ Departamento de Ciências Agrárias e Ambientais, Universidade Estadual de Santa Cruz - UESC
}

Recebido em 15 de Dezembro de 2008

Aceito em 23 de Março de 2009

\section{Resumo}

Objetivou-se verificar a ocorrência de anticorpos anti-Toxoplasma gondii em suínos criados e abatidos no Estado da Bahia. Foram coletadas e examinadas 465 amostras de sangue de suínos provenientes de criaçôes de diferentes locais desse estado. Para a pesquisa de anticorpos anti-T. gondii, foi utilizada a técnica de Imunoadsorçâo Enzimática (ELISA) e considerados positivos todos os animais com títulos iguais ou maiores que 1:16. Desses, 18,27\% (85/465) foram positivos para anticorpos anti-T. gondii, sendo 30,76\% (24/78) em Ilhéus, $18,10 \%$ (21/116) em Itabuna e 14,76\% (40/271) em Simōes Filho. Foram observadas diferenças significativas quanto ao sexo dos animais $(p=0,0171)$, ao sistema de criação $(\mathrm{p}=0,0002)$ e à procedência dos animais $(\mathrm{p}=0,0278)$ no município de Itabuna. Anticorpos anti-T. gondii foram encontrados nos animais estudados, podendo ser estes animais fonte de infecção para a populaçáo humana local.

Palavras-chave: ELISA, Toxoplasma gondii, suínos, zoonose.

\begin{abstract}
This study was performed to verify the occurrence of anti-Toxoplasma gondii antibodies in swine raised and slaughtered in the state of Bahia, Brazil. Four hundred sixty five swine blood samples from farms of different cities had been collected and examined. Anti-T. gondii antibodies was detected by the enzyme-linked immunosorbent assay (ELISA) and considered positive all the animals with equal or bigger headings than 1:16. From these, $18.27 \%(85 / 465)$ of total sample were positive for T. gondii, 30.76\% (24) in Ilhéus, 18.10\% (21/116) in Itabuna and 14.76\% (40/271) in Simões Filho. Significant differences were observed regarding animal sex $(\mathrm{p}=0.0171)$, raising system $(\mathrm{p}=0.0002)$ and origin of the animals $(\mathrm{p}=0.0278)$ in the city of Itabuna. The occurrence of anti-T. gondii antibodies shows that swine can be a source of infection for the local human population.
\end{abstract}

Keywords: ELISA, Toxoplasma gondii, pigs, zoonosis.

A toxoplasmose é uma zoonose de distribuição mundial que acomete o homem e outros animais de sangue quente (mamíferos e aves), sendo causada pelo protozoário Toxoplasma gondii (DUBEY; BEATTIE, 1988).

Em animais de produção, cistos teciduais de T. gondii são frequentemente observados em tecidos de suínos, ovinos e caprinos infectados (TENTER et al., 2000). Os problemas causados por T. gondii nesses animais são morte, reabsorção e mumificação embrionária, assim como aborto (DUBEY, 2004). Particularmente em suínos, a infecção pelo T. gondii provoca alterações clínicas como

\footnotetext{
*Autor para correspondência: George R. Albuquerque Departamento de Ciências Agrárias e Ambientais,

Universidade Estadual de Santa Cruz - UESC, BA 415, km 16, CEP 45662-000 Salobrinho, Ilhéus - BA, Brasil; e-mail: gralbu@uesc.br Apoio: CNPq, FAPESB, CAPES
}

hipertermia, anorexia, prostração e corrimento nasal, entretanto o principal problema é de ordem reprodutiva (VIDOTTO et al., 1987). No Brasil, a soroprevalência em suínos varia de $0 \%$ (BRANDÃO et al., 2006) a 90\% (GUIMARÃES et al., 1992) e náo foram encontrados estudos de toxoplasmose em suínos no Nordeste do Brasil.

Os humanos podem adquirir a toxoplasmose pelo consumo de carne crua ou mal cozida contaminada com cistos teciduais viáveis ou pela ingestáo de comida ou água contaminada com oocistos esporulados de fezes de gatos (TENTER et al., 2000; DUBEY; JONES, 2008).

Devido aos prejuízos causados para os animais de produção, por estes atuarem como fonte de infecçáo ao homem, e à falta de informaçōes sobre a ocorrência do agente em suínos no Estado da 
Bahia, objetivou-se com este estudo verificar a ocorrência de anticorpos anti-T. gondii em suínos criados e abatidos nesse estado.

Foram coletadas amostras de sangue de 465 suínos, acima de quatro meses de idade, em pequenos criatórios no município de Ilhéus, em um matadouro clandestino no município de Itabuna e no matadouro frigorífico sob Inspeção Federal no município de Simóes Filho. Os suínos foram provenientes de distintos criadores de municípios do Estado da Bahia. Para os animais abatidos nos matadouros, a amostragem populacional foi obtida utilizando-se o programa Epi-Info Versão 3.4, com expectativa de prevalência de $20 \%$ da infecção por T. gondii; e para os suínos criados no município de Ilhéus, a população estudada foi de todos os animais encontrados nas sete propriedades analisadas.

O sangue foi coletado por punção da veia cava, ou no momento da sangria dos animais, e transportado ao Laboratório de Parasitologia Veterinária da Universidade Estadual de Santa Cruz (UESC). Os soros foram separados, identificados e armazenados a $-20^{\circ} \mathrm{C}$ até o momento das análises sorológicas.

Para a pesquisa de anticorpos anti- $T$. gondii, foi utilizado o teste de Imunoadsorção Enzimática (ELISA), conforme Suaréz-Aranda et al. (2000) com algumas modificaçóes. Utilizou-se a antígeno na diluição de $50 \mu \mathrm{g} \cdot \mathrm{mL}^{-1}$, todas as lavagens foram feitas com PBS contendo $0,1 \%$ de Tween 20 (PBS-T), o bloqueio foi feito com PBS-T contendo $5 \%$ de leite desnatado e a reação foi interrompida com $50 \mu \mathrm{L} /$ poço de $\mathrm{H}_{2} \mathrm{SO}_{4} 2 \mathrm{~N}$. O antígeno solúvel foi obtido do exsudato peritoneal de camundongos infectados com a cepa $\mathrm{RH}$ de $T$. gondii, conforme Silva et al. (2005).

Para análise das variáveis sexo, sistema de criação e procedência dos animais foi usado o teste Qui-quadrado $\left(\chi^{2}\right)$ com nível de significância de $5 \%$, utilizando-se o programa EPI INFO versão 3.4. Os sistemas de criação foram caracterizados como granjas comerciais ou criaçóes rústicas.

Dos 465 soros testados, 18,27\% (85/465) (IC 95\% = 21,7\%$14,7 \%)$ foram positivos para anticorpos anti-T. gondii, sendo $30,76 \%(24 / 78)($ IC $95 \%=40,9 \%-20,5 \%)$ de positividade em Ilhéus, 18,10\% (21/116) (IC 95\% = 25,1\%-11,1\%) em Itabuna e 14,76\% (40/271) (IC 95\% = 10,7\%-18,7\%) em Simóes Filho.

Os valores encontrados neste estudo são semelhantes aos de Tsutsui et al. (2003) e Santos et al. (2005). Já Suarez-Aranda et al. (2000) e Moura et al. (2007) encontraram resultados inferiores aos observados neste estudo, com positividade de 9,6 e 8,54\%. Por outro lado, Guimarães et al. (1992) e Cavalcante et al. (2006) obtiveram resultados superiores, com positividade de 90 e 37,5\%, respectivamente, mostrando a grande diferença das prevalências observadas em diferentes regióes do Brasil.

Quando se analisa a variável sexo frente à positividade do total de suínos (Tabela 1$)$, não se encontra diferença $(\mathrm{p}=0,0773)$, corroborando os resultados de Garcia et al. (1999) e Millar et al. (2008) no Paraná, Brasil. Contudo, quando se analisa cada município individualmente (Tabela 2), observa-se que, entre os animais de Itabuna, existe diferença significativa $(\mathrm{p}=0,0171)$ e isso pode ser explicado pelo abate de algumas matrizes neste município, que apresentaram uma alta positividade (4/7-57,1\%). As matrizes, por serem animais mais velhos, têm uma maior chance de se infectarem. O mesmo foi obtido por Moura et al. (2007), que verificaram uma maior ocorrência de sororreagentes entre as fêmeas adultas.
Tabela 1. Resultado do teste de Qui-quadrado em 465 amostras de soro de suínos avaliados quanto à presença de anticorpos anti-Toxoplasma gondii e das variáveis sexo, sistema de criação e procedência, Estado da Bahia, 2008.

\begin{tabular}{cccc}
\hline \multirow{2}{*}{ Variáveis } & \multicolumn{2}{c}{ Animais } & \multirow{2}{*}{ Valor de p } \\
\cline { 2 - 3 } & Positivos & Negativos & \\
\hline Sexo & 34 & 195 & 0,0773 \\
Macho & 51 & 185 & \\
Fêmea & & & 0,0002 \\
Sistema de criaçáo & 55 & 316 & \\
Granja & 30 & 64 & \\
Rústico & & & 0,0278 \\
Procedência & 45 & 149 & \\
Abate clandestino & 40 & 231 & \\
Abate SIF* & & & \\
\hline
\end{tabular}

*Sistema de Inspeção Federal.

Tabela 2. Associação entre a soropositividade ao ELISA para IgG anti-Toxoplasma gondii e sexo dos suínos, no município de Itabuna, Estado da Bahia, Brasil, 2008.

\begin{tabular}{cccc}
\hline \multirow{2}{*}{$\begin{array}{c}\text { Soropositivos para } \\
\text { T. } \text { gondii }\end{array}$} & \multicolumn{2}{c}{ Sexo } & Total \\
\cline { 2 - 3 } & Machos & Fêmeas & \\
\hline Sim & 4 & $17\left(4^{\mathrm{a}}\right)$ & 21 \\
Não & 48 & $47(3)$ & 95 \\
Total & 52 & $64(7)$ & 116 \\
\hline
\end{tabular}

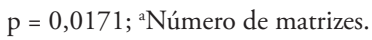

O sistema de criação foi determinante na soropositividade dos suínos ( $\mathrm{p}=0,0002)$. Os animais confinados em granjas apresentaram menor soropositividade que aqueles criados de maneira rústica (Tabela 1), possivelmente devido a uma menor exposição dos animais aos oocistos presentes no solo e na água. Resultados semelhantes foram obtidos por Tsutsui et al. (2003) e Giessen et al. (2007).

Houve diferença entre os animais provenientes de abate clandestino, que apresentaram valores de ocorrência mais altos, quando comparados aos abatidos em Sistema de Inspeção Federal $(\mathrm{SIF})(\mathrm{p}=0,0278)$. Tais resultados podem ser explicados porque os suínos abatidos com inspeçáo foram todos oriundos de granjas comerciais, enquanto os de abate clandestino foram provenientes também de criaçóes rústicas.

\section{Agradecimentos}

Aos Doutores Italmar Teodorico Navarro, da Universidade Estadual de Londrina (UEL) e Francisco Carlos Rodrigues de Oliveira, da Universidade Estadual do Norte Fluminense (UENF), pelo fornecimento dos soros controles. 


\section{Referências}

BRANDÃO, G. P. et al. Characterization of Toxoplasma gondii from domestic animals from Minas Gerais, Brazil. Parasite, v. 13, n. 2, p. 143-149, 2006.

CAVALCANTE, G. T. et al. Seroprevalence of Toxoplasma gondii antibodies in cats and pigs from rural Western Amazon, Brazil. Journal of Parasitology, v. 92, n. 4, p. 863-864, 2006.

DUBEY, J. P. Toxoplasmosis: a waterborne zoonosis. Veterinary Parasitology, v. 126, n. 1-2, p. 57-72, 2004.

DUBEY, J. P.; BEATTIE, C. P. Toxoplasmosis of animals and man. Boca Raton: CRC Press, 1988. p. 220.

DUBEY, J. P.; JONES, J. L. Toxoplasma gondii infection in humans and animals in the United States. International Journal for Parasitology, v. 38, n. 11, p. 1257-1278, 2008.

GARCIA, J. L. et al. Soroprevalência do Toxoplasma gondii, em suínos, bovinos, ovinos, e equinos, e sua correlação com humanos, felinos e caninos, oriundos de propriedades rurais do norte do Paraná-Brasil. Ciência Rural, v. 29, n. 1, p. 91-97, 1999.

GIESSEN, J. et al. Seroprevalence of Trichinella spiralis and Toxoplasma gondii in pigs from different housing systems in the Netherlands. Veterinary Parasitology, v. 148, n. 3-4, p. 371-374, 2007.

GUIMARÁES, A. M. et al. Frequência de anticorpos anti-Toxoplasma gondii em suínos da raça Piau. Arquivo Brasileiro de Medicina Veterinária e Zootecnia, v. 44, n. 1, p. 69-71, 1992.
MILLAR, P. R. et al. Toxoplasma gondii: estudo soro-epidemiológico de suínos da região Sudoeste do Estado do Paraná. Pesquisa Veterinária Brasileira, v. 28, n. 1, p. 15-18, 2008.

MOURA, A. B. et al. Ocorrência de anticorpos contra Toxoplasma gondii em suínos e ovinos abatidos no município de Guarapuava, PR, Brasil. Revista Brasileira de Parasitologia Veterinária, v. 16, n. 1, p. 54-56, 2007.

SANTOS, C. B. A. et al. First isolation and molecular characterization of Toxoplasma gondii from finishing pigs from São Paulo State, Brazil. Veterinary Parasitology, v. 131, n. 3-4, p. 207-211, 2005.

SILVA, D. A. O. Evaluation of homologous, heterologous, and affinity conjugates for the serodiagnosis of Toxoplasma gondii and Neospora caninum in maned wolves (Chrysocyon brachyurus). Journal of Parasitology, v. 91, n. 5, p. 1212-1216, 2005.

SUARÉZ-ARANDA F. et al. The prevalence and avidity of Toxoplasma gondii $\operatorname{IgG}$ antibodies in pigs from Brazil and Peru. Veterinary Parasitology, v. 91, n. 1-2, p. 23-32, 2000.

TENTER, A. M.; HECKEROTH, A. R.; WEISS, L. M. Toxoplasma gondii: from animals to humans. International Journal for Parasitology, v. 30, n. 12-13, p. 1217-1258, 2000.

TSUTSUI, V. S. et al. Soroepidemiologia e fatores associados à transmissão do Toxoplasma gondii em suínos do norte do Paraná. Archives of Veterinary Science, v. 8, n. 2, p. 27-34, 2003.

VIDOTTO, O. et al. Toxoplasmose experimental em porcas gestantes: alteraçōes patológicas e reisolamento. Arquivo Brasileiro de Medicina Veterinária e Zootecnia, v. 39, n. 5, p. 795-814, 1987. 